\title{
Increased Somatomedin and Cartilage Metabolic Activity in Rabbit Fetuses Injected with Insulin In Utero
}

\author{
D. J. Hill and R. D. G. Milner \\ Department of Paediatrics, University of Sheffield, Children's Hospital, Sheffield, England
}

Summary. The effect of insulin injection in fetal rabbits on plasma somatomedin activity and cartilage metabolism was investigated. One fetus in each of 12 litters was injected with 1 unit of insulin zinc suspension subcutaneously on day 27 of gestation and a control fetus was injected with the same volume of $0.154 \mathrm{~mol} / \mathrm{l}$ saline. The litter was delivered by caesarean section on day 29 and each fetus identified. Plasma somatomedin activity was determined by fetal rabbit cartilage bioassay. Costal cartilage from individual fetuses was incubated in medium containing $\left[{ }^{3} \mathrm{H}\right]$ thymidine or $\left[{ }^{35} \mathrm{~S}\right]$ sulphate as indicators of cell replication and matrix synthesis respectively. Individual values for somatomedin activity or cartilage isotope uptake were ranked within a litter. In each case the rank in the litter of the insulin-injected fetus, but not the saline-injected fetus, was significantly higher than the mean rank of the litter. Insulin did not stimulate cartilage metabolism in vitro.

Key words: Rabbit fetus, insulin, somatomedin activity, cartilage growth.

Insulin may have a profound effect on fetal metabolism and body weight as seen in the heavy, hyperinsulinaemic infants of untreated diabetic mothers and the low birthweight of infants with diabetes mellitus [1]. Much of the weight discrepancy can be accounted for by excess or reduced adipose tissue, and to a lesser extent by alterations in visceral mass [2]. There are so far only isolated reports of an anabolic role for insulin in utero on skeletal and muscular tissue $[3,4$, 5].

In the postnatal mammal skeletal growth is predominantly under pituitary growth hormone control mediated by a group of hormonal factors collectively known as somatomedin [6]. Somatomedin activity is also present in the fetus but is not dependent on the presence of growth hormone [7]. The purpose of this study was to investigate the response of somatomedin activity and of biochemical parameters of skeletal growth in the fetal rabbit following treatment with insulin in utero. Somatomedin activity was measured using rabbit fetal cartilage which is the appropriate physiological target. This assay reflects the total biological activity rather than that of any specific somatomedin peptide.

\section{Materials and Methods}

\section{Chemicals}

Cartilage incubations were performed using Waymouth's medium MB752/1 (Flow Laboratories, Irvine, Ayr) supplemented with sodium bicarbonate $(10 \mathrm{mM} / \mathrm{l})$, penicillin $(100 \mathrm{U} / 1)$, streptomycin $(100 \mu \mathrm{g} / \mathrm{ml})$ and $\mathrm{N}-2$-hydroxyethyl piperazine-N'-ethane sulphonic acid (HEPES) buffer $(20 \mathrm{mM} / \mathrm{l})$, and adjusted to $\mathrm{pH} 7.4$ with $\mathrm{NaOH}$ before sterilisation by passage through Millipore filters $(0.45 \mu \mathrm{m})$. Bovine zinc insulin suspension, lente, and soluble insulin were obtained from AB Insulin Ltd, London. $\left[{ }^{35}\right.$ S $]$ sulphate and $\left[{ }^{3} \mathrm{H}\right]$ thymidine were obtained from the Radiochemical Centre, Amersham, Bucks.

\section{Fetal Injection In Utero}

Pregnant Dutch rabbits (food and water supplied ad libitum) of 27 days gestation were prepared for operation and the abdominal cavity opened as described previously [7]. The first fetus exposed within the uterus was partially removed from the abdomen and injected subcutaneously with $25 \mu \mathrm{l}$ of zinc insulin suspension (1U) through the uterine wall in the dorsal thoracic area. An adjacent fetus was given the same volume of $0.154 \mathrm{~mol} / 1$ saline. Treated fetuses were identified from a coding of suture threads tied to the uterine wall. The fetuses were returned to the abdominal cavity and the maternal incision closed. The order of injection was sometimes reversed.

\section{Somatomedin Assay}

The doe was killed on day 29 of gestation by cervical dislocation and the litter delivered by caesarean section. Fetuses weighed $19-40 \mathrm{~g}$ at delivery (mean $30 \mathrm{~g}$ ). Individual fetal blood samples 
were collected into heparinised tubes following fetal decapitation, and the plasma separated by centrifugation at $4^{\circ} \mathrm{C}$. Maternal plasma was also collected and all plasma samples were stored at $-20^{\circ} \mathrm{C}$ until assay. Plasma somatomedin activity was assayed by the uptake of $\left[{ }^{35} \mathrm{~S}\right]$ sulphate $(1 \mu \mathrm{Ci} / \mathrm{ml}$ medium $)$ into fetal rabbit costal cartilage pieces in vitro as described by Hill et al. [7] using five (occasionally four) fetuses from each litter. The total assay volume was reduced to $1 \mathrm{ml}$ in order to perform parallel line assays on the small volume of individual fetal plasma available. Each assay contained plasma in duplicate from each fetus within a litter at concentrations of $10 \%$ and $2.5 \%$ plasma together with maternal plasma and a standard rabbit plasma, each present in duplicate at concentrations of $10 \%, 5 \%$ and $2.5 \%$ plasma. The standard plasma was part of a pool taken from two month old male rabbits and was given an arbitrary somatomedin activity of $1 \mathrm{U} / \mathrm{ml}$.

\section{Cartilage Incubation}

Four costal cartilage sections from each fetus were incubated in plasma-free medium in quadruplicate tubes under the same conditions as the somatomedin assay. Two tubes contained $\left.{ }^{35} \mathrm{~S}\right]$ sulphate and the other two $\left[{ }^{3} \mathrm{H}\right]$ thymidine, each $1 \mu \mathrm{Ci}$ in a total incubation volume of $1 \mathrm{ml}$. Cartilage was excised within $1 \mathrm{~h}$ of death and isotope uptake in vitro was taken to reflect the previous endogenous metabolic activity in utero.

\section{Radioimmunoassay of Insulin}

Plasma insulin levels in fetal plasma were measured by radioimmunoassay [8] using ${ }^{125} 1$ insulin (Radiochemical Centre, Amersham, Bucks), human insulin standard (MR71) and insulin reagent (RD12) from Wellcome Reagents Ltd, Beckenham. The volume of standard solution or plasma was $50 \mu$ l. The limit of sensitivity was $12 \mu \mathrm{U} / \mathrm{ml}$. All samples were measured in two assays, the interassay coefficient of variation was $12 \%$, the intra-assay coefficient of variation was $5 \%$. Separation of free from bound insulin was performed by centrifugation.

\section{Statistical Analysis}

The validity of somatomedin assays was assessed by standard bioassay statistics [7]. Valid estimations were expressed as a relative potency compared to the standard plasma. A total of 12 somatomedin assays were performed, each containing plasma from all the fetuses within a litter together with corresponding maternal plasma and standard plasma. An arbitrary rejection level of 0.45 was adopted for the index of precision $(\lambda)$ which resulted in 4 assays being rendered invalid. The individual $\lambda$ values for the remaining 8 assays are given in Table 1 . As $\lambda$ is of limited value since it reflects only how the standard response varies in log-dose, precision was also assessed by Finney's g statistic [7]. Values of g were all less than 0.1 and compared favourably with reported values for other cartilage assays $[18,21]$. The inter-assay coefficient of variation was $17 \%$ for a test plasma present in 3 successive assays separate from the experimental series. Large intra- and interlitter variations in growth parameters exist in the fetal rabbit making the data discontinuous. The effects of insulin and saline injections in utero were therefore assessed by rank test in which each fetus within the litter was given a rank for the parameter under consideration, the highest value ranking one. If the experimental procedure had no effect the rank of the treated fetus would not be expected to differ significantly from the mean rank of the litter which is referred to as the expected rank. Differences between observed and expected rank were compared by Students' t-test.

\section{Results}

\section{Fetal and Maternal Somatomedin Activity}

The individual somatomedin values of the 8 litters of fetuses and their mothers are shown in Table 1. In each litter the somatomedin activity of the insulin injected fetus ranked first, second or third, whereas that of the saline injected control was distributed randomly. The mean rank of the insulin injected fetus was significantly higher than that of the litter whereas the mean rank of the saline injected control was not (Table 2). The rank of the insulin injected fetus was also significantly higher in the litter than the rank of the saline injected fetus.

A wide range of somatomedin values existed within most litters and also between litters. No correlation existed between mean litter somatomedin activity and maternal values. For litters in which all data were available the mean fetal somatomedin activity for 42 fetuses (excluding insulin treated fetuses) was $1.04 \mathrm{U} / \mathrm{ml}$ (range 0.11-4.49) compared to a mean maternal value from 7 determinations of $1.51 \mathrm{U} / \mathrm{ml}$ (range $0.56-2.86$ ). The difference was not significant and individual fetuses often had a higher somatomedin than the corresponding maternal value.

\section{Fetal Cartilage Metabolism}

The uptake in vitro of $\left[{ }^{35} \mathrm{~S}\right]$ sulphate and $\left[{ }^{3} \mathrm{H}\right]$ thymidine into the costal cartilage of individual fetuses is shown in Tables 3 and 4 respectively. When figures were ranked for the uptake of isotope within each litter the mean observed rank of the fetus given insulin was significantly higher than the expected value in both cases (Table 2). The mean observed rank for the fetus given saline was in both cases similar to the expected value. Large inter- and intra-litter variation was again seen in isotope uptake. For individual fetuses the uptake of $\left[{ }^{35}\right.$ S] sulphate was significantly correlated with the uptake of $\left[{ }^{3} \mathrm{H}\right]$ thymidine (linear correlation coefficient $\mathrm{r} 0.33 \mathrm{df} 49, \mathrm{p}<0.05$ ) but no significant relationship existed between fetal somatomedin activity and the corresponding uptake of either isotope into costal cartilage.

\section{Insulin In Vitro}

In 8 of the somatomedin assays the assay cartilage was also exposed to insulin both with and without fetal rabbit plasma. The direct addition of both zinc insulin suspension and soluble insulin in a range of 8 concentrations from $10 \mu \mathrm{U} / \mathrm{ml}$ to $1 \mathrm{U} / \mathrm{ml}$ in the $\mathrm{ab}$ sence of plasma failed to stimulate the uptake of $\left[{ }^{35} \mathrm{~S}\right]$ sulphate into fetal cartilage above the levels seen in medium alone. Both insulin preparations were also incubated with cartilage at concentrations of $1 \mathrm{mU} / 1$ and $10 \mathrm{mU} / \mathrm{l}$ in the presence of pooled, normal fetal 
Table 1. Plasma somatomedin activity $(\mathrm{U} / \mathrm{ml})$ of individual rabbit fetuses in 8 litters and their mothers

\begin{tabular}{|c|c|c|c|c|c|c|c|c|c|c|c|c|c|c|c|}
\hline \multirow{2}{*}{ Litter } & \multirow{2}{*}{$\lambda$} & \multirow{2}{*}{$\begin{array}{l}\text { Finney's g } \\
0.05 \text { level }\end{array}$} & \multirow{2}{*}{$\begin{array}{l}\text { Maternal } \\
\text { somatomedin } \\
\text { activity }\end{array}$} & \multicolumn{12}{|c|}{ Fetal somatomedin activity } \\
\hline & & & & \multicolumn{6}{|c|}{ Right uterine horn } & \multicolumn{6}{|c|}{ Left uterine horn } \\
\hline 1 & 0.43 & 0.08 & NP & & & & 1.11 & 0.60 & 0.77 & $(0.45)$ & 1.08 & 0.50 & 0.81 & & \\
\hline 2 & 0.32 & 0.05 & 1.95 & 0.36 & 0.37 & 0.70 & 4.49 & Invd & 0.90 & 1.68 & Dead & 1.03 & $(1.22)$ & 2.56 & \\
\hline 3 & 0.36 & 0.04 & 2.86 & & & & 0.52 & $(0.35)$ & 0.32 & NP & 0.32 & & & & \\
\hline 4 & 0.29 & 0.03 & 0.63 & & 0.22 & 0.15 & 0.14 & 0.29 & (Dead) & Dead & 0.48 & 0.20 & 0.30 & & \\
\hline 5 & 0.33 & 0.06 & 1.21 & & & & & 2.28 & $(0.86)$ & 0.73 & 0.96 & 2.04 & 1.14 & 0.58 & \\
\hline 7 & 0.45 & 0.08 & 2.03 & & & & & 0.72 & 0.66 & 0.70 & 2.10 & Invd & 1.17 & 0.83 & $\begin{array}{ll} & 1.89\end{array}$ \\
\hline 10 & 0.45 & 0.09 & 0.56 & & & & 0.19 & $(0.17)$ & 0.26 & 0.11 & 0.40 & 1.09 & & & \\
\hline 12 & 0.24 & 0.03 & 1.32 & & & & & 2.22 & 2.41 & 2.26 & 2.07 & 1.97 & 1.52 & $(2.46)$ & 2.82 \\
\hline
\end{tabular}

The mother and all fetuses within a litter were included in the same somatomedin assay

Figures are arranged to display the position of each fetus within the uterus. Insulin-treated fetuses are italicized and saline-treated animals are in parentheses. Somatomedin determinations shown as invalid (Invd) were rejected due to lack of parallelism with the standard. Animals from which insufficient plasma was obtained for somatomedin assay are shown as NP

Table 2. Mean ( \pm SD) ranked position of the insulin-treated and saline-treated fetus within the litters for plasma somatomedin activity and the incorporation of $\left[{ }^{35} \mathrm{~S}\right]$ sulphate and $\left[{ }^{3} \mathrm{H}\right]$ thymidine into costal cartilage in plasma-free medium

\begin{tabular}{llll}
\hline & $\begin{array}{l}\text { Plasma } \\
\text { somatomedin activity }\end{array}$ & $\begin{array}{l}{\left[^{35} \text { S]sulphate uptake in }\right.} \\
\text { cartilage }\end{array}$ & $\begin{array}{l}{\left[^{3} \mathrm{H}\right] \text { thymidine }} \\
\text { uptake in cartilage }\end{array}$ \\
\hline $\begin{array}{l}\text { Number of litters } \\
\begin{array}{l}\text { Mean expected position of insulin-treated } \\
\text { fetus in litter }\end{array}\end{array}$ & 8 & 12 & 8 \\
$\begin{array}{l}\text { Mean observed position of insulin-treated } \\
\text { fetus in litter }\end{array}$ & $3.5 \pm 0.8$ & $3.7 \pm 0.6$ & $3.7 \pm 0.5$ \\
$\begin{array}{l}\text { Number of litters } \\
\begin{array}{l}\text { Mean expected position of saline-treated } \\
\text { fetus in litter }\end{array}\end{array}$ & $1.9 \pm 0.8^{\mathrm{b}}$ & $1.3 \pm 0.6^{\mathrm{c}}$ & $2.0 \pm 1.6^{\mathrm{a}}$ \\
$\begin{array}{l}\text { Mean observed position of saline-treated } \\
\text { fetus in litter }\end{array}$ & $3.5 \pm 0.8$ & $3.7 \pm 0.7$ & 8 \\
\hline
\end{tabular}

Student's t-test for paired results

Mean expected position (mean litter rank) compared with observed position: ${ }^{a} p<0.02,{ }^{b} p<0.005,{ }^{c} p<0.001$

Observed rank insulin-injected fetus compared with observed rank saline-injected fetus: ${ }^{\mathrm{d}} \mathrm{p}<0.001,{ }^{\mathrm{p}} \mathrm{p}<0.005$

rabbit plasma from animals of 29 day gestation, at concentrations of $10 \%, 5 \%$ and $2.5 \%$. When the dose response in the presence of fetal plasma alone was defined as unity, the apparent potency $( \pm S D)$ in the presence of the lower insulin concentration was $0.77 \pm 0.23 \mathrm{U} / \mathrm{ml}$ and for the higher concentration $1.07 \pm 0.28 \mathrm{U} / \mathrm{ml}$. Insulin present in vitro did not therefore appear to stimulate cartilage isotope uptake directly or modify the stimulatory effect of fetal plasma.

\section{Fetal Plasma Insulin}

Plasma insulin concentrations were measured in individual fetuses of 11 litters at the time of caesarean section. Only one of the insulin-injected fetuses had a plasma insulin concentration of more than $400 \mu \mathrm{U} / \mathrm{ml}$ and in three other litters the insulin-injected fetus had the highest plasma insulin of the litter. Plasma insulin concentrations for insulin-injected fetuses were in the range $12->400 \mu \mathrm{U} / \mathrm{ml}$ (mean approximately $99 \mu \mathrm{U} / \mathrm{ml}$ ) and for saline-injected fetuses $<12-177 \mu \mathrm{U} / \mathrm{ml}$ (mean approximately $43 \mu \mathrm{U} / \mathrm{ml}$ ). The plasma insulin concentrations of uninjected fetuses ranged from less than 12 to $365 \mu \mathrm{U} / \mathrm{ml}$ (mean approximately $54 \mu \mathrm{U} / \mathrm{ml}$ ), values similar to those reported earlier for rabbit fetuses at term [9]. Individual fetal plasma insulin levels did not correlate with fetal somatomedin activity.

\section{Discussion}

Treatment of the rabbit fetus with insulin resulted in increased costal cartilage growth as seen from the raised isotope uptake into the cartilage in vitro following excision. Both $\left[{ }^{35} \mathrm{~S}\right]$ sulphate and $\left[{ }^{3} \mathrm{H}\right]$ thy- 
Table 3. Uptake of $\left[{ }^{35} \mathrm{~S}\right] \mathrm{sulphate}(\mathrm{cpm} / \mathrm{mg})$ into costal cartilage from individual fetuses in 12 litters after incubation in plasma-free medium

\begin{tabular}{|c|c|c|c|c|c|c|c|c|c|c|c|c|c|}
\hline \multirow{3}{*}{$\frac{\text { Litter }}{1}$} & \multicolumn{13}{|c|}{ Cartilage isotope uptake } \\
\hline & \multicolumn{7}{|c|}{ Right uterine horn } & \multicolumn{6}{|c|}{ Left uterine horn } \\
\hline & & & & 354 & 442 & 437 & (358) & 380 & 353 & 330 & & & \\
\hline 2 & 2894 & 2205 & 2876 & 2704 & 1479 & 2556 & 3152 & Dead & 1303 & $(2206)$ & 3536 & & \\
\hline 3 & & & & 2334 & $(1532)$ & 1253 & 2191 & 831 & & & & & \\
\hline 4 & & 131 & 104 & 114 & 218 & (Dead) & Dead & 137 & 112 & 120 & & & \\
\hline 5 & & & & & 3594 & (1019) & 939 & 726 & 520 & 1220 & 1409 & & \\
\hline 6 & & & & & 1324 & 1569 & 860 & 551 & 1649 & 2324 & $(1878)$ & & \\
\hline 7 & & & & & 261 & 362 & 539 & 354 & 412 & 250 & 286 & (301) & 694 \\
\hline 8 & & 423 & 689 & 456 & 1087 & 649 & 885 & $(387)$ & & & & & \\
\hline 9 & & & & 159 & $(168)$ & 156 & 138 & 149 & 119 & 143 & 130 & & \\
\hline 10 & & & & 943 & $(1001)$ & 1352 & 450 & 409 & 1170 & & & & \\
\hline 11 & & & 557 & (263) & 468 & 338 & 276 & 198 & 233 & & & & \\
\hline 12 & & & & & 430 & 996 & 675 & 552 & 981 & 818 & $(544)$ & 1354 & \\
\hline
\end{tabular}

Presentation of results as in Table 1

Figures represent the mean of duplicate determinations (coefficient of variation of $27 \%$ )

Table 4. Uptake of $\left[{ }^{3} \mathrm{H}\right]$ thymidine (cpm/mg) into costal cartilage from individual fetuses in 8 litters after incubation in plasma-free medium

\begin{tabular}{|c|c|c|c|c|c|c|c|c|c|c|c|c|}
\hline \multirow{3}{*}{$\frac{\text { Litter }}{5}$} & \multicolumn{12}{|c|}{ Cartilage isotope uptake } \\
\hline & \multicolumn{6}{|c|}{ Right uterine horn } & \multicolumn{6}{|c|}{ Left uterine horn } \\
\hline & & & & 4806 & (2336) & 1602 & 3355 & 1413 & 2142 & 2388 & & \\
\hline 6 & & & & 1227 & 951 & 1408 & 859 & 1144 & 1662 & $(3278)$ & & \\
\hline 7 & & & & 947 & 582 & 1094 & 592 & 868 & 575 & 857 & $(1402)$ & 1490 \\
\hline 8 & 4268 & 3661 & 1704 & 3683 & 4574 & 5388 & $(4090)$ & & & & & \\
\hline 9 & & & 365 & $(228)$ & 206 & 272 & 306 & 813 & 481 & 642 & & \\
\hline 10 & & & 1282 & $(1296)$ & 2612 & 2025 & 1895 & 2427 & & & & \\
\hline 11 & & 3547 & $(2309)$ & 2389 & 1296 & 2554 & 2345 & 2307 & & & & \\
\hline 12 & & & & 2622 & 1367 & 1912 & 2120 & 3183 & 2112 & (2004) & 2006 & \\
\hline
\end{tabular}

Presentation of results as in Table 1

Figures represent the mean of duplicate determinations (coefficient of variation $22 \%$ )

midine uptake were increased suggesting that there was an increase in both cell replication and the turnover of sulphated mucopolysaccharides. As described originally by Salmon and Daughaday [10], the cartilage uptake of isotope in vitro is an indicator of skeletal growth in vivo, and in the postnatal mammal is dependent on the circulating levels of somatomedin activity, the factor thought to stimulate skeletal tissues directly. There is growing evidence that skeletal growth in the fetus is also stimulated by somatomedin $[11,12,13]$ although the possibility of other anabolic hormones directly stimulating the tissues in vivo has not been ruled out. When insulin was incubated with fetal rabbit cartilage in vitro it did not stimulate the uptake of $\left.{ }^{35} \mathrm{~S}\right]$ sulphate above basal levels, even though the range of concentrations used extended from sub-physiological to pharmacological levels. It seems unlikely that the raised cartilage metabolic activity resulted from a direct stimulation by insulin in vivo.

Somatomedin activity was also increased in the plasma of the insulin-treated fetuses although this could have been explained by an alteration by insulin of the cartilage response to fetal plasma. No additional uptake of $\left.{ }^{35} \mathrm{~S}\right]$ sulphate was seen when fetal cartilage was incubated with fetal plasma in the presence of insulin compared to plasma alone. The use of the fetal rabbit cartilage assay for the estimation of somatomedin activity ensures that a physiologically relevant cartilage response was observed. The use of a more established cartilage assay such as postnatal pig may have yielded better assay precision but would not have reflected the response of fetal tissues to the fetal hormonal stimulus. There is evidence that the sensitivity of fetal rabbit cartilage to a somatomedin stimulus differs markedly from the postnatal cartilage response [19]. Analysis of the individual fetal plasma insulin levels revealed that the majority of the injected insulin had disappeared from the circulation after two days. The stimulatory activity of fetal rabbit plasma can therefore be assumed to reflect the somatomedin content. It has not yet been demonstrated whether fetal rabbit somatomedin activity is wholly derived from the fetus or whether some activity is due to placental transfer. As wide differences in potency were found for the somatome- 
din levels of individual fetuses within the same litter, some of which were on occasion much greater than the corresponding maternal values, it would seem unlikely that placental transfer contributes greatly to the fetal somatomedin activity. It is not surprising that such a range of fetal somatomedin values exists considering the similarly large variation in endogenous cartilage metabolic activity, and the wide range in body weight of the fetuses at delivery. A similar large variation in cord blood somatomedin activity for human infants has been reported [20].

An insulin-dependent increase in plasma somatomedin could have occurred either by a stimulation of the fetal tissues responsible for somatomedin production, or indirectly by the alteration of an intermediate hormonal or nutrient factor which consequently regulated production. If such a hormonal factor exists it is difficult to speculate on its identity, as the removal of pituitary hormones by decapitation of the rabbit fetus in utero has been shown to have no depressive effect on fetal plasma somatomedin activity [8]. A direct control of somatomedin generation is possible as several fetal tissues have been shown to be rich in insulin receptors [13], and insulin has been reported to increase somatomedin levels in the postnatal rat in vivo $[14,15]$ and its release from the perfused rat liver [16]. The fetal tissues responsible for somatomedin production have not been identified.

The absence of a correlation between somatomedin and cartilage metabolic activity for individual fetuses suggests that hormonal factors are not the overriding determinant of fetal skeletal growth. In a polytocous species such as the rabbit the growth of a fetus will be related to the efficiency of its placenta in supplying an adequate nutrient supply and fetal rabbit body weight increases with increasing placental weight [17]. Our results suggest that in these experiments insulin may have had an anabolic role in promoting skeletal growth via the fetal somatomedin pathway.

Acknowledgements. D. J. Hill holds the J. G. Graves Medical Research Fellowship of the University of Sheffield. We are grateful to the Medical Research Council for financial support and to Dr. N. R. J. Fieller, Department of Probability and Statistics, University of Sheffield, for the development of the bioassay program used in the measurement of somatomedin activity. The program uses the two numerical algorithms group library routines S14AAF and D01AGF.

\section{References}

1. Milner RDG (1979) The role of insulin and glucagon in fetal growth and metabolism. In: Visser HKA (ed) Nutrition and metabolism of the fetus and infant. Martinus Nijhoff, The Hague, p 3-18
2. Naeye RL (1965) Infants of diabetic mothers: a quantitative, morphologic study. Pediatrics 35: 980-988

3. Cheek DB, Brayton JB, Scott RE (1974) Overnutrition, overgrowth and hormones (with special reference to the infant born of the diabetic mother). Adv Exp Med Biol 49: 47-72

4. Susa JB, McCormick KL, Widness JA, Singer DB, Oh W, Adamsons K, Schwartz R (1979) Primary hyperinsulinaemia in the rhesus monkey fetus: effects on fetal growth and hepatic composition. Pediatr Res 13: 482

5. Kim YS, Jatoi I, Kim RE (1980) Neonatal macrosomia in maternal diabetes. Diabetologia 18: 407-412

6. Van Wyk JJ, Underwood LE (1975) Relation between growth hormone and somatomedin. Annu Rev Med 26: 427-441

7. Hill DJ, Davidson P, Milner RDG (1979) Retention of plasma somatomedin activity in the foetal rabbit following decapitation in utero. J Endocrinol 81: 93-102

8. Hales CN, Randle PJ (1963) Immunoassay of insulin with insulin-antibody precipitate. Biochem J 88: 137-146

9. Milner RDG (1969) Plasma and tissue insulin concentrations in foetal and postnatal rabbits. J Endocrinol 43: 119-124

10. Salmon WD, Daughaday WH (1957) A hormonally controlled serum factor which stimulates sulfate incorporation by cartilage in vitro. $\mathrm{J}$ Lab Clin Med 49: 825-836

11. Gluckman PD, Brinsmead MW (1976) Somatomedin in cord blood: relationship to gestational age and birth size. $\mathrm{J}$ Clin Endocrinol Metab 43: 1378-1381

12. Ashton IK, Francis MJO (1978) Response of chondrocytes isolated from human foetal cartilage to plasma somatomedin activity. J Endocrinol 76: 473-477

13. D'Ercole AJ, Foushee DB, Underwood LE (1976) Somatome$\operatorname{din} \mathrm{C}$ receptor ontogeny and levels in porcine fetal and human cord serum. J Clin Endocrinol Metab 43: 1069-1077

14. Phillips LS, Young HS (1976) Nutrition and somatomedin. II. Serum somatomedin activity and cartilage growth activity in streptozotocin diabetic rats. Diabetes 25: 516-527

15. Franklin RC, Rennie GE, Cameron DP (1979) Serum levels of the acid-ethanol soluble component of non-suppressible insulin-like activity in untreated and treated streptozotocin-diabetic rats. J Endocrinol 81: 331--337

16. Daughaday WH, Phillips LS, Mueller MC (1976) The effects of insulin and growth hormone on the release of somatomedin by the isolated rat liver. Endocrinology 98: 1214-1219

17. Rosahn PD, Greene HSN (1936) The influence of intrauterine factors on the fetal body weight of rabbits. J Exp Med 63: 901-921

18. Hall K (1970) Quantitative determination of the sulphation factor activity in human serum. Acta Endocrinol (Kbh) 63: 338-350

19. Beaton GR (1976) Studies on serum somatomedin activity and cartilage responsiveness in the regulation of growth. Thesis, Fac Sci., Univ Witwatersrand, Johannesburg

20. Ashton IK, Vesey J (1978) Somatomedin activity in human cord plasma and relationship to birth size, insulin, growth hormone and prolactin. Early Human Develop 2: 115-122

21. Ashton IK, Francis MJO (1977) An assay for plasma somatomedin: ${ }^{3} \mathrm{H}$ thymidine incorporation by isolated rabbit chondrocytes. J Endocrinol 74: 205-212

Received: October 16, 1979,

and in revised form: March 20, 1980

Dr. D. J. Hill

Department of Paediatrics

Children's Hospital

Sheffield S10 2TH, England 